\title{
Rehabilitation of Huanglongbing- affected Citrus Trees Using Severe Pruning and Enhanced Foliar Nutritional Treatments
}

\author{
Robert E. Rouse, Monica Ozores-Hampton ${ }^{1}$, Fritz M. Roka, \\ and Pamela Roberts \\ University of Florida, Institute of Food and Agricultural Sciences, Southwest \\ Florida Research \& Education Center, 2685 SR 29 N, Immokalee, FL 34142
}

Additional index words. HLB, citrus greening, PCR, nutrition, orange, 'Valencia', cost-benefit analysis, buckhorning

\begin{abstract}
Citrus trees affected by huanglongbing (HLB) become diminished, weak, and develop dieback resulting in reduced production. Decline in fruit yield ultimately prevents economically acceptable commercial citrus production. The objectives of this study were to evaluate the effects of severe pruning in combination with an enhanced foliar nutritional treatment on growth, yield, and juice quality of HLB-affected orange trees. The bacterial titer within the trees was monitored before and after treatments, and a cost-benefit analysis provided an economic evaluation of the treatments. Fifteen-yearold 'Valencia' orange (Citrus sinensis Macf.) trees on Swingle citrumelo rootstocks $[C$. paradisi $\times$ Poncirus trifoliata (L.) Raf.] with $100 \%$ incidence of HLB, confirmed by realtime polymerase chain reaction (PCR), were severely pruned back to the main scaffold branches. Between 2010 and 2015, foliar nutrients were sprayed on both pruned and nonpruned trees to target new flush growth. Three enhanced nutritional foliar treatments were evaluated and compared with a control foliar nutritional treatment that was considered to be a standard practice before endemic HLB. The enhanced nutritional treatments included a mixture of micro- and macronutrients commonly known as the "Boyd cocktail," a micronutrient package labeled Fortress (c) (Florida Phosphorus LLC, Key Largo, FL) sprayed with potassium nitrate $\left(\mathrm{KNO}_{3}\right)$, and the Fortress (C) micronutrient package sprayed with urea. The experiment was a split-plot with seven replications, with pruning as the main plots, and a foliar nutritional treatment as subplots. Tree pruning was performed in Feb. 2010 before the spring flush. Pruned trees grew longer shoots than the controls the year after pruning. Canopy volume and leaf area were greater with nonpruned trees, but the chlorophyll content per $\mathrm{cm}^{2}$ leaf area was higher in the pruned trees compared with nonpruned trees in 3 years of the 5-year experiment. Pruned and nonpruned trees bloomed and set fruit the first year of the experiment in the spring of 2010-11. The fruit crop for the 2010-11 and 2014-15 seasons, and the overall total fruit crop for the 2010-15 season on pruned trees were significantly lower than those on nonpruned trees. However, no significant yield differences were found between pruned and nonpruned trees in the 2011-12, 2012-13, and 2013-14 growing seasons. Fruit yields from pruned trees never surpassed the yields from nonpruned trees, and this was possibly due to the severe-pruning treatment. Thus, severe pruning, as used in this trial, was not cost effective through the first 5 years after pruning. The rapid regrowth response of the pruned trees, however, may indicate that a reduced pruning approach could be effective at rejuvenating the HLB-affected trees, and an alternative to tree removal and replanting. Enhanced foliar nutrition treatments provided some yield benefits, especially in the early years of the trial. However, the enhanced foliar nutrition treatments did not prove to be cost effective.
\end{abstract}

Huanglongbing, also known as HLB and citrus greening, is a bacterial disease caused by the bacterium Candidatus Liberibacter asiaticus (CLas) and vectored by the Asian citrus psyllid (ACP, Diaphorina citri). Symptoms of HLB include asymmetrical chlorosis of the leaves, often referred to as "blotchy mottle." Eventually, dieback of the shoot and

Received for publication 27 June 2016. Accepted for publication 18 Nov. 2016.

1Corresponding author. E-mail: Ozores@ufl.edu. widespread endemic reality of HLB, they abandoned attempts to control inoculum levels of CLas through eradication of symptomatic trees. Instead, Florida growers searched for cultural practices that would maintain production from HLB-affected trees until tolerant or resistant rootstocks and scion cultivars became available.

Pruning and applying plant nutrients through foliar sprays started two cultural practices that growers started implementing. Information on their overall effectiveness, however, has been limited. Pruning has been a recognized practice in Florida to rehabilitate freeze-damaged trees (Davies and Jackson, 2009; Fake, 2012; Wright and Kelly, 2008; Zekri and Rouse, 2013). If a freeze kills a significant portion of a tree's canopy, the tree can be "buckhorned," which means pruning a tree back to its scaffold limbs. The severe pruning results in the maximum stimulation and the strongest regrowth (Nesbitt, 2010; Rouse and Zekri, 2012). To our knowledge, buckhorning or pruning HLB-affected trees, however, has not been investigated before this trial. Severe root dieback occurs with HLB (Bové, 2006), and it was not known whether an affected tree could withstand the severe pruning to reestablish a canopy and produce an acceptable fruit yield.

Many Florida citrus growers have implemented foliar treatments of micro- and macronutrients as a method to satisfy a tree's nutrient requirements after HLB has blocked nutrient flow via the phloem (Gottwald et al., 2012). The enhanced foliar nutritional treatments do not have bactericidal effects on CLas; however, they may be employed to maintain the nutritional health and production of HLB-affected trees (Rouse et al., 2010, 2012). Since 2006, some growers using foliar nutrition treatments on HLB-affected citrus trees have harvested 'Hamlin' and 'Valencia' oranges at yields that are close to those obtained before the appearance of HLB (Rouse et al., 2010, 2012).

Planting and replanting citrus were at an all-time low between 2006 and 2010. Many growers were reluctant to reset missing trees in existing groves or replant entire blocks because of concern that the young trees would rapidly succumb to HLB and never reach profitable production (Florida Agricultural Statistics Service, 2014). By 2010, the Florida citrus industry realized that there was a need to either begin replanting trees or wait for greater confidence in replanting. At the same time, there was mounting evidence that an enhanced foliar nutritional treatment was having a positive effect on the health of existing trees (Rouse et al., 2010, 2012).

The objectives of this study were 1) to evaluate the severe pruning in combination with foliar nutrition treatments on tree growth, yield and juice quality and 2) to evaluate the cost effectiveness of rehabilitating a tree through pruning and an enhanced foliar nutritional treatment. 


\section{Materials and Methods}

The study was conducted at the University of Florida/Institute of Food and Agricultural Sciences/Southwest Florida Research and Education Center (UF/IFAS/SWFREC) located just north of Immokalee, FL. The study was conducted in a 2.02 ha block of 16 year-old 'Valencia' orange (Citrus sinensis Macf.) trees on Swingle citrumelo rootstock [C. paradisi $\times$ Poncirus trifoliata (L.) Raf.]. The experimental design was a split-plot with pruned and nonpruned as the main plots and four nutritional treatments as subplots. The experimental unit was 10 trees, and each treatment combination was replicated seven times. Tree density was 326 trees/ha planted $4.6 \mathrm{~m}$ in-row by $6.7 \mathrm{~m}$ between rows with microsprinkler irrigation and nearly level soil classified as Immokalee fine sand (sandy, siliceous, and hyperthemic Arenic Haplaquods), with the spodic horizon lying within $1 \mathrm{~m}$ beneath the ground surface before bedding (Obreza and Collins, 2008). The planting was a typical flatwoods citrus grove bedded with two tree rows per 13.4-m wide raised bed. The experiment began in Feb. 2010. Rows of trees on the west side of each two-row bed were pruned to $1.22-\mathrm{m}$ wide in the row and topped 1.22-m high. Pruning was done using a commercial mechanical hedger and topping machine. Large pruned limbs were removed from the site, and smaller pruned limbs were shredded. Trees on the east row of each bed remained unpruned. This section of the citrus grove was identified as having similar soils, similar drainage, and similar-sized trees before pruning. Therefore, there were no differences in conditions between the east and west rows.

Four foliar nutrient treatments were applied to the new flush of the pruned and the nonpruned trees with a John Bean Redjet (Durand-Wayland, LaGrange, GA) citrus speed sprayer. The products and amounts of the foliar applied nutrient treatments are shown in Table 1. Three foliar nutritional treatments were applied four times per year: the first application in March when the spring flush emerged, two applied during the summer flush in June and late July, and the final application to fall flush in September. The fourth foliar treatment, referred to as the control, involved spraying a chelated mixture of micronutrients once a year, immediately after the July summer flush. In accordance with the UF/ IFAS recommendations for citrus (Obreza and Morgan, 2008), a dry calcium nitrate fertilizer, nitrogen-phosphorus-potassium analysis
(9N-0.4P-11.6K), which also contained magnesium $(\mathrm{Mg})$, manganese $(\mathrm{Mn})$, zinc $(\mathrm{Zn})$, iron $(\mathrm{Fe})$, copper $(\mathrm{Cu})$, and boron $(\mathrm{B})$, was broadcasted across all plots at a rate of 2015 $\mathrm{kg} /$ ha/year (Table 2).

Data collection consisted of growth measurements expressed by shoot length, tree volume, total shoot leaf area, and leaf chlorophyll concentration or soil-plant analysis development (SPAD) using a SPAD-502 chlorophyll meter (Minolta Camera Co., Tokyo, Japan). Shoot length was determined once a year after the recent flush on 11 May 2010, 1 Aug. 2011, 10 Dec. 2012, 16 July 2013, and 27 May 2014. Five adjacent trees in the middle of each plot were chosen, and five branches were randomly selected equally spaced around the tree including a high and low height. The five measurements were averaged to represent the shoot length of that experimental unit.

Tree canopy volume was determined by measuring the canopy in north-south and eastwest directions and the tree height. The canopy volume was determined by the formula $V=$ $0.5236 \times d^{2} h$ where $d=$ tree diameter and $h=$ tree height (Rouse and Wutscher, 1985).

The total shoot leaf area measurements corresponded to same dates as when shoot length was measured. The largest leaf on the

Table 1. Nutrient components and amounts per application of the foliar nutritional treatment applied to pruned and nonpruned Huanglongbing affected citrus trees at the University of Florida/Southwest Florida Research and Education Center, Immokalee, FL, season 2010-14. Products and amounts applied in 1164 L/ha of water with a citrus speed sprayer.

\begin{tabular}{|c|c|c|c|c|c|c|c|}
\hline \multicolumn{2}{|c|}{ Control $^{z}$} & \multicolumn{2}{|c|}{ Boyd mixture } & \multicolumn{2}{|c|}{ Fortress $^{\mathrm{y}} / \mathrm{KNO}_{3}$} & \multicolumn{2}{|c|}{ Fortress $^{\mathrm{y}} /$ urea } \\
\hline Product/unit & Amount & Product/unit & $\overline{\text { Amount }}$ & Product/unit & $\overline{\text { Amount }}$ & Product/unit & Amount \\
\hline & & $\mathrm{K}^{\mathrm{x}}(\mathrm{kg})$ & 1.69 & $\mathrm{~N}(\mathrm{~kg})$ & 1.55 & Fortress $(\mathrm{kg})$ & 2.80 \\
\hline & & $\mathrm{N}(\mathrm{kg})$ & 0.61 & Fortress $(\mathrm{kg})$ & 2.80 & & \\
\hline & & $\mathrm{Mn}(\mathrm{kg})$ & 1.47 & & & & \\
\hline & & Mo (g) & 9.91 & & & & \\
\hline & & $\mathrm{Zn}(\mathrm{kg})$ & 0.45 & & & & \\
\hline
\end{tabular}

${ }^{\mathrm{z}}$ Control is a commercial liquid micronutrient product containing chelated micronutrients $\mathrm{S}(4.0 \%), \mathrm{Fe}(3.5 \%), \mathrm{Mg}(1.5 \%), \mathrm{Mn}(0.75 \%), \mathrm{Mo}(0.003 \%), \mathrm{Zn}$ $(0.75 \%), \mathrm{Cu}(0.06 \%)$, and B $(0.16 \%)$.

${ }^{\mathrm{y}}$ Fortress (Florida Phosphorus LLC, Key Largo, FL). Sources: P (58.4\%), Ca (4.0\%), Mg (3.0\%), Mn (3.5\%), Cu (0.6\%), B (0.6\%), and zinc phosphite (6.0\%), Co $(0.1 \%)$, and Ni EDTA $(0.1 \%)$.

${ }^{\mathrm{x}} \mathrm{N}=$ nitrogen $\mathrm{P}=$ phosphorus; $\mathrm{K}=$ potassium; $\mathrm{Ca}=$ calcium; $\mathrm{Mg}=$ magnesium; $\mathrm{S}=$ sulfur; $\mathrm{Fe}=$ iron; $\mathrm{B}=$ boron; $\mathrm{Zn}=$ zinc $; \mathrm{Mn}=$ manganese $; \mathrm{Cu}=$ copper; $\mathrm{Mo}=$ molybdenum; $\mathrm{Ni}=$ nickel; $\mathrm{Co}=$ cobalt; $\mathrm{KNO}_{3}=$ potassium nitrate.

Table 2. Nutrients applied by ground, foliar, and annual total by nutritional treatment to pruned and nonpruned Huanglongbing affected citrus trees at the University of Florida/Southwest Florida Research and Education Center, Immokalee, FL, season 2010-14.

\begin{tabular}{|c|c|c|c|c|c|c|c|c|c|c|c|c|c|c|}
\hline \multirow[b]{3}{*}{ Nutritional treatment } & \multicolumn{6}{|c|}{ Macronutrients } & \multicolumn{8}{|c|}{ Micronutrients } \\
\hline & $\mathrm{N}^{\mathrm{z}}$ & $\mathrm{P}$ & $\mathrm{K}$ & $\mathrm{Ca}$ & $\mathrm{Mg}$ & $\mathrm{S}$ & $\mathrm{Fe}$ & $\mathrm{B}$ & $\mathrm{Zn}$ & $\mathrm{Mn}$ & $\mathrm{Cu}$ & Mo & $\mathrm{Ni}$ & $\mathrm{Co}$ \\
\hline & \multicolumn{14}{|c|}{ Dry fertilizer ground application $(\mathrm{kg} / \mathrm{ha} / \mathrm{yr})$} \\
\hline All treatments-control ${ }^{\mathrm{y}}$ & 181.3 & 8.8 & 234.1 & 228.5 & 22.77 & 125.1 & 0.40 & 0.20 & 0.60 & 0.60 & 0.20 & - & - & - \\
\hline \multicolumn{15}{|c|}{ Enhanced foliar nutritional treatment $(\mathrm{kg} / \mathrm{ha} / \mathrm{yr})$} \\
\hline Control & - & - & - & - & 0.09 & 0.2 & 0.20 & 0.01 & 0.04 & 0.04 & 0.003 & 0.00002 & - & - \\
\hline Boyd & 18.6 & 32.4 & 85.5 & - & 3.29 & 14.8 & - & - & 3.97 & 14.33 & - & 0.08 & - & - \\
\hline Fortress $/ \mathrm{KNO}_{3}$ & 3.1 & 2.8 & 8.5 & 0.45 & 0.34 & - & - & 0.067 & 0.67 & 0.39 & 0.067 & 0.011 & 0.011 & 0.011 \\
\hline Fortress/urea & 11.8 & - & - & 0.45 & 0.34 & - & - & 0.067 & 0.67 & 0.39 & 0.067 & 0.011 & 0.011 & 0.011 \\
\hline \multicolumn{15}{|c|}{ Annual total (dry and foliar) nutrients applied ( $\mathrm{kg} / \mathrm{ha} / \mathrm{yr})$} \\
\hline Control & 181.3 & 8.8 & 234.1 & 228.5 & 22.86 & 125.4 & 0.60 & 0.21 & 0.65 & 0.65 & 0.203 & 0.00002 & - & - \\
\hline Boyd & 200.0 & 41.2 & 319.6 & 228.5 & 26.06 & 140.0 & 0.40 & 0.20 & 4.58 & 14.93 & 0.20 & 0.08 & - & - \\
\hline Fortress $/ \mathrm{KNO}_{3}$ & 184.5 & 11.7 & 242.7 & 228.9 & 23.10 & 125.1 & 0.40 & 0.27 & 1.28 & 1.00 & 0.27 & 0.01 & 0.011 & 0.011 \\
\hline Fortress/urea & 193.2 & 8.8 & 234.1 & 228.9 & 23.10 & 125.1 & 0.40 & 0.27 & 1.28 & 1.00 & 0.27 & 0.01 & 0.011 & 0.011 \\
\hline
\end{tabular}

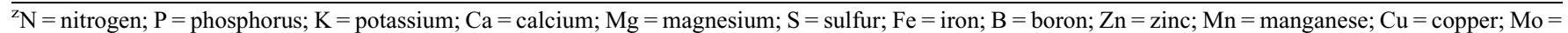
molybdenum; $\mathrm{Ni}=$ nickel; $\mathrm{Co}=$ cobalt; $\mathrm{KNO}_{3}=$ potassium nitrate.

${ }^{\mathrm{y}}$ Same amount of dry fertilizer was also applied to Boyd, Fortress/ $\mathrm{KNO}_{3}$, and Fortress/urea. 
shoot selected for length measurement was measured along its midrib. Total shoot leaf area was calculated by the formula $[0.099+1.64 \times$ (length of largest leaf $\times$ number of shoot leaves)]
(Spann and Heerema, 2010). Leaf chlorophyll was determined from SPAD readings on $13 \mathrm{Dec}$. 2010, 6 July 2011, 30 Oct. 2012, 22 July 2013, and 15 Oct. 2014 from the previously selected five trees for shoot length and total shoot leaf area. Then five mature leaves from five different mature shoots were selected randomly on the east and west sides on each of plot $(25$

Table 3. Effects of the foliar nutrient treatments applied to the pruned and nonpruned Huanglongbing affected citrus trees on annual tree shoot length, volume, leaf area, and soil-plant analysis development (SPAD) at the University of Florida/Southwest Florida Research and Education Center, Immokalee, FL, season $2010-14$.

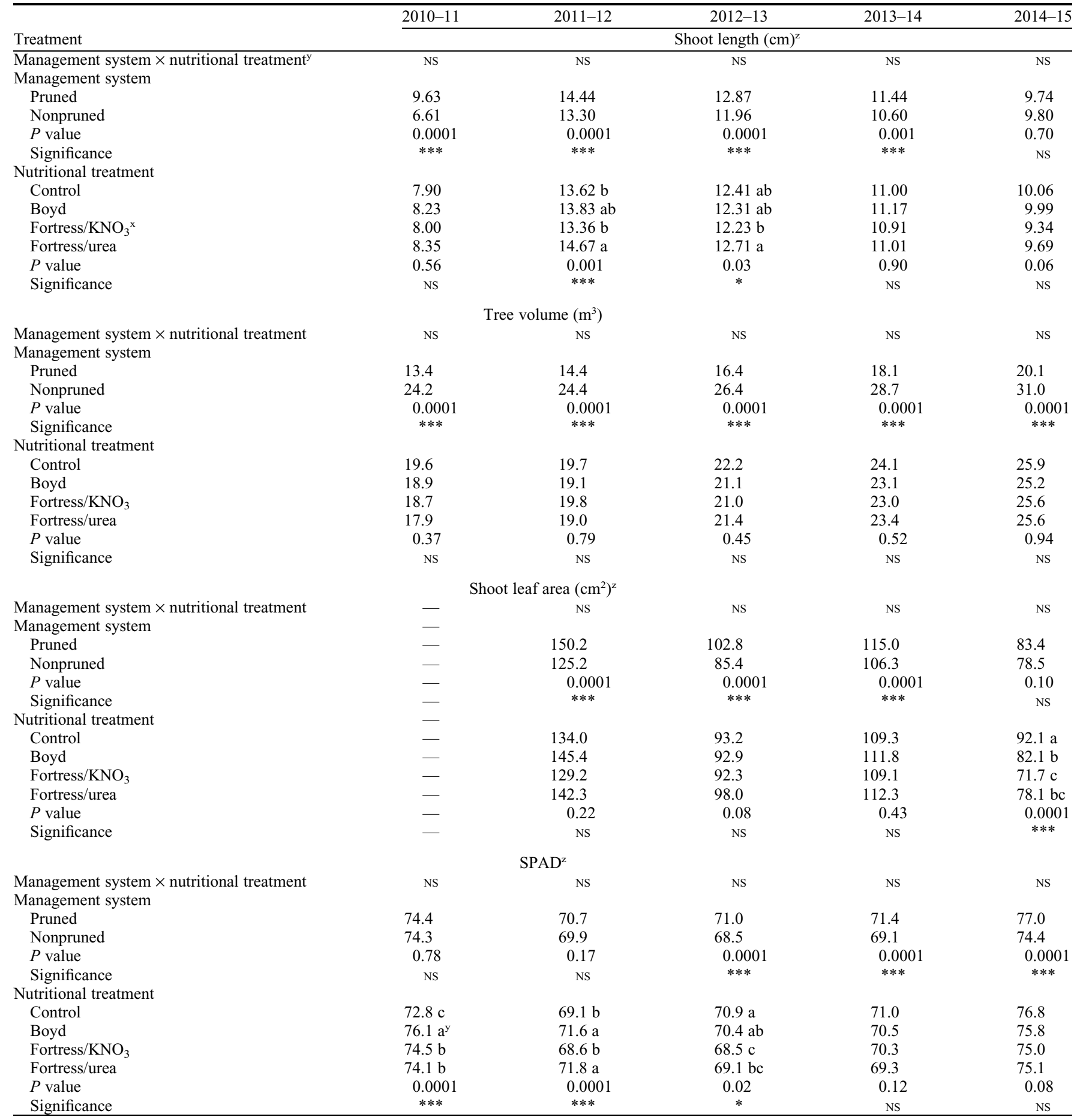

${ }^{\mathrm{z}}$ Shoot leaf areas were determined on randomly selected mature shoots around the tree from the spring growth flush. Five shoots were selected on 10 trees in the plot (length of the largest leaf was measured). Tree volume was determined by measuring the canopy in a north-south and east-west direction and the tree height. The shoot leaf area was calculated with the formula [0.099 $+1.64 \times$ (length of largest leaf $\times$ number of shoot leaves)]. Leaf chlorophyll was determined from SPAD readings as the mean of five randomly selected mature leaves on five different mature shoots from the spring flush.

${ }^{\mathrm{y}}$ When interactions were not significant means separation between management systems was performed to Tukey-Kramer honestly significant difference test at $5 \%$ and among nutritional treatment by different letters according to Duncan's multiple range test at 5\%.

${ }^{\mathrm{x}} \mathrm{KNO}_{3}=$ potassium nitrate.

NS, ${ }^{*}, * *, * *$ Nonsignificant or significant at $P \leq 0.05,0.01$, or 0.001 , respectively. 
Table 4. Effects of the foliar nutrient treatments applied to pruned and nonpruned Huanglongbing affected citrus trees on crop yield at the University of Florida/ Southwest Florida Research and Education Center, Immokalee, FL, season 2010-14.

\begin{tabular}{|c|c|c|c|c|c|c|}
\hline \multirow[b]{2}{*}{ Treatment } & $2010-11$ & $2011-12$ & $2012-13$ & $2013-14$ & $2014-15$ & $2011-15$ Total \\
\hline & \multicolumn{6}{|c|}{ Yield (40.8 kg-boxes/ha) } \\
\hline Management system $\times$ nutritional treatment & NS & NS & NS & NS & NS & NS \\
\hline \multicolumn{7}{|l|}{ Management system ${ }^{z}$} \\
\hline Pruned & 66.4 & 465.6 & 238.8 & 538.2 & 632.3 & 1,869 \\
\hline Nonpruned & 168.0 & 481.9 & 255.2 & 559.0 & 715.1 & 2,005 \\
\hline$P$ value & 0.0001 & 0.35 & 0.19 & 0.24 & 0.005 & 0.02 \\
\hline Significance & $* * *$ & NS & NS & NS & $* *$ & $*$ \\
\hline \multicolumn{7}{|l|}{ Nutritional treatment } \\
\hline Control & $94.8 \mathrm{~b}$ & $249.0 \mathrm{~b}$ & 249.0 & 532.5 & 633.6 & 1,831 \\
\hline Boyd & $117.1 \mathrm{a}$ & $539.2 \mathrm{a}$ & 230.2 & 523.9 & 668.9 & 1,958 \\
\hline Fortress $/ \mathrm{KNO}_{3}{ }^{\mathrm{y}}$ & $128.4 \mathrm{a}$ & $458.2 \mathrm{ab}$ & 249.0 & 572.8 & 693.1 & 1,961 \\
\hline Fortress/urea & $128.4 \mathrm{a}$ & $259.6 \mathrm{~b}$ & 259.6 & 564.6 & 699.5 & 2,000 \\
\hline$P$ value & 0.04 & 0.0003 & 0.40 & 0.16 & 0.33 & 0.15 \\
\hline Significance & $*$ & $* * *$ & NS & NS & NS & NS \\
\hline
\end{tabular}

${ }^{\mathrm{z}}$ When interactions were not significant means separation between management systems was performed to Tukey-Kramer honestly significant difference test at $5 \%$ and among nutritional treatments by different letters according to Duncan's multiple range test at $5 \%$.

${ }^{\mathrm{y}} \mathrm{KNO}_{3}=$ potassium nitrate.

NS, *,**,***Nonsignificant or significant at $P \leq 0.05,0.01$, or 0.001 , respectively.

measurements). The Minolta SPAD-502 is a hand-held, self-calibrating, convenient, and nondestructive lightweight device used to measure the concentration of chlorophyll present in plant leaves (Minolta, 1989; Yadava, 1985).

All fruit from each tree were harvested and weighed annually. Fruit yield by treatment was reported as boxes/ha ( $40.8 \mathrm{~kg} / \mathrm{box})$ and was derived by multiplying average yield per tree by 326 , the tree density. A $41-\mathrm{kg}$ fruit sample was collected from each experimental unit and transported to the UF/IFAS/Citrus Research and Education Center, Lake Alfred, FL for juice quality analysis. Juice was extracted with a Florida Department of Agricultural and Consumer Services-approved FMC (Food Machinery Corporation, Philadelphia, PA) commercial juice extractor and analyzed for percent juice, titratable acid (TA), total soluble solids (TSS) as Brix, and TSS/TA ratio.

A 10-leaf sample from each tree was collected and run with real-time PCR for detection of HLB bacteria. Total DNA was extracted from HLB-symptomatic leaves in which the petioles chopped and processed by the modified Tris-Base $\beta$-mercaptoethanol method of $\mathrm{Li}$ et al. (2006). Reactions were carried out in a 7500 Fast Real Time PCR System (Applied Biosystems, Foster City, $\mathrm{CA})$. The $\mathrm{Ct}$ value is considered positive for CLas at 32 or below, negative at 36 or higher, and inconclusive between these two values.

The trial was monitored for psyllids, and management was by application of labeled insecticides to all trees in the study using a John Bean Redjet citrus speed sprayer (Durand-Wayland, Inc., Lagrange, GA). Sprays for psyllids were made four to five times per year including two dormant season applications.

Tree growth, yield, and juice quality measurements were analyzed as a split-plot design using analysis of variance, and means between the pruning treatments were separated by the Tukey-Kramer honest significant difference test, and among the nutritional treatments by Duncan's multiple range test,
$5 \%$, level (SAS version 9.3, SAS Institute Inc., Cary, NC, 2011).

Prices of materials were collected from fertilizer and chemical product vendors to estimate the costs of each foliar treatment. The results from a 2014 custom rate survey provided estimates of pruning, brush removal, dry fertilizer, and foliar application costs (Roka et al., 2015). Partial budget analysis compared economic outcomes of the individual treatments. Partial budgeting evaluated only the net change in costs and revenue among all treatments.

\section{Results}

PCR leaf analysis results (not shown) confirmed that all citrus trees in the trial were positive for CLas at the start of the trial in 2010 and each year afterward in 2011 and 2012. The PCR values ranged from 20.83 to 30.40 . The control trees showed HLB-symptomatic leaves throughout the year and became visibly yellow and chlorotic during the fall and winter. The Fortress-treated trees exhibited some chlorotic leaves on select shoots and moderate visible symptomatic leaves during fall and winter. The Boyd-treated trees remained mostly free of HLB-symptomatic leaves during the growing season with only minor-symptomatic leaves during the winter.

Tree growth. Annual growth measurements of shoot length, tree volume, leaf area, and SPAD by treatment are shown in Table 3 . Statistical analysis showed a lack of interaction between pruning and foliar nutritional treatment for any of the tree growth parameters; therefore, the pruned and foliar nutrition treatments were analyzed as main effects.

Pruned trees had significantly longer shoot growth than nonpruned trees each year, except during 2014-15. Among the nutritional treatments, Fortress/urea produced longer shoots than either the control or Fortress $/ \mathrm{KNO}_{3}$ in 2011-12, 2012-13, respectively. None of the foliar nutrition treatments produced any significant differences in shoot length in 2010-11, 2013-14, and 2014-15. Tree volume increased in pruned and nonpruned trees from 2010 to
2015. There were no differences in tree volume among the foliar treatments. Pruned trees had greatest shoot leaf area than nonpruned trees from 2011 to 2014, but no differences in 2014 15. The control foliar treatments had the greatest and Fortress/urea produced smaller shoot leaf area than any other foliar treatments in 2011-15. There were no differences in shoot leaf area among the foliar treatments in 201213 and 2013-14. Pruned trees had higher chlorophyll content than nonpruned trees in 2012-13, 2013-14, and 2014-15. There were no differences in SPAD between pruned and nonpruned trees in 2010-11 and 2011-12 and among the foliar treatments in 2013-14 and 2014-15. Boyd had higher chlorophyll content than the other foliar treatments in 2010-11; however, in 2011-12 it was similar to Fortress/urea and in 2012-13 it was similar to the control.

Yield data. Statistical analysis of yield indicated no interaction between pruning and foliar nutritional treatment. Consequently, yield differences were analyzed separately for the pruning and foliar nutritional treatment (Table 4). Yield differences between pruned and nonpruned trees were significant in the first year after pruning (2010-11), with nonpruned trees yielding on average 101 boxes per ha (41 boxes/acre) more than pruned trees. Yields from pruned trees rebounded during the second year (2011-12) as the trees reestablished a canopy and set fruit. Yield differences between pruned and nonpruned trees were not significantly different during the second, third, and fourth years of the trial. In 2014-15, yields from nonpruned trees again were significantly higher than from pruned trees by nearly 83 boxes/ha. Overall, yields from nonpruned trees were numerically higher than from pruned trees during each year of the trial. The cumulative yield difference was significant with nonpruned trees producing 136 boxes/ha more than from pruned trees $(P<0.05)$.

Enhanced foliar nutritional treatments made a statistically significant contribution to yield in both pruned and nonpruned trees during the first and second years of the trial. In 2010-11, the enhanced foliar treatments 
Table 5. Effects of the foliar nutrient treatments applied to pruned and nonpruned Huanglongbing citrus affected trees on 'Valencia' juice quality at the University of Florida/Southwest Florida Research and Education Center, Immokalee, FL, season 2010-14.

\begin{tabular}{|c|c|c|c|c|c|}
\hline \multirow[b]{2}{*}{ Treatment } & Juice $\%$ & Titratable acid (TA) \% & Total soluble solids (TSS) ${ }^{\circ}$ Brix & TSS/TA ratio & $\mathrm{kg}$ solids/box \\
\hline & \multicolumn{5}{|c|}{$2011-12$} \\
\hline Pruned & 45.42 & 0.51 & 9.51 & 18.84 & 1.42 \\
\hline$P$ value & 0.003 & 0.001 & 0.0001 & 0.0002 & 0.01 \\
\hline Significance & $* *$ & $* * *$ & $* * *$ & $* * *$ & $* *$ \\
\hline Fortress $/ \mathrm{KNO}_{3}{ }^{\mathrm{y}}$ & 46.67 & 0.50 & 10.10 & 20.33 & 1.63 \\
\hline Fortress/urea & 47.82 & 0.53 & 10.40 & 19.50 & 1.73 \\
\hline$P$ value & 0.89 & 0.07 & 0.39 & 0.34 & 0.85 \\
\hline Significance & NS & NS & NS & NS & NS \\
\hline \multicolumn{6}{|c|}{$2012-13$} \\
\hline Management system $\times$ nutritional treatment ${ }^{z}$ & NS & NS & NS & NS & NS \\
\hline Significance & NS & $* * *$ & $* *$ & * & $*$ \\
\hline \multicolumn{6}{|l|}{ Nutritional treatment } \\
\hline Control & 60.80 & 0.58 & 11.16 & 19.15 & 2.77 \\
\hline Boyd & 58.87 & 0.57 & 10.98 & 19.35 & 2.64 \\
\hline Fortress $/ \mathrm{KNO}_{3}$ & 61.17 & 0.58 & 11.20 & 19.45 & 2.79 \\
\hline Fortress/urea & 60.53 & 0.59 & 11.38 & 19.29 & 2.81 \\
\hline$P$ value & 0.20 & 0.60 & 0.28 & 0.94 & 0.05 \\
\hline Significance & NS & NS & NS & NS & NS \\
\hline \multicolumn{6}{|c|}{ 2013-14 } \\
\hline Management system $\times$ nutritional treatment & NS & NS & NS & NS & NS \\
\hline \multicolumn{6}{|l|}{ Management system } \\
\hline Pruned & 59.77 & 0.79 & 10.94 & 13.99 & 2.66 \\
\hline Nonpruned & 59.49 & 0.84 & 11.26 & 13.52 & 2.73 \\
\hline
\end{tabular}

${ }^{\mathrm{z}}$ When interactions were not significant means separation between management systems was performed to Tukey-Kramer honestly significant difference test at $5 \%$ and among nutritional treatment by different letters according to Duncan's multiple range test at 5\%.

${ }^{\mathrm{y}} \mathrm{KNO}_{3}=$ potassium nitrate.

Ns, ${ }^{*}, * *, * *$ Nonsignificant or significant at $P \leq 0.05,0.01$, or 0.001 , respectively.

Table 6. Cost of pruning as a strategy to rehabilitate Huanglongbing affected citrus trees at the University of Florida/Southwest Florida Research and Education Center, Immokalee, FL, season 2010-14.

\begin{tabular}{|c|c|c|}
\hline$\overline{\text { Practice }}$ & Description & $(\$ / \mathrm{ha})$ \\
\hline Hedger/topper/ha & $2010^{z}$ & 222 \\
\hline Debris clean-up/ha & $2010^{z}$ & 178 \\
\hline Yield loss & $\begin{array}{l}101 \text { boxes/ha } \\
\text { yield difference } \\
\$ 9.71 / 40.8 \text { kg-box }^{\mathrm{x}}\end{array}$ & 981 \\
\hline Total cost of prunin & treatment & 1,381 \\
\hline
\end{tabular}
1,381

${ }^{\mathrm{z}}$ Custom rate charge (Roka et al., 2015).

${ }^{\mathrm{y}}$ Data from Table 4, 2011 yield difference between unpruned and pruned trees.

${ }^{\mathrm{x}}$ See Table 7 for $2010-11$ average on-tree price for Valencia oranges.

increased yield by at least $22.3-33.6$ boxes/ha over the control. In 2011-12, the Boyd treatment yielded 290.2 boxes/ha more than the control, and 81.0 and 279.6 boxes/ha more than the Fortress with $\mathrm{KNO}_{3}$ and urea, respectively. However, the yield from the Boyd treatment was not statistically different from the yields of Fortress with $\mathrm{KNO}_{3}$ during this second year of the trial. Yield differences between the enhanced foliar treatments and the control during the third, fourth, and fifth years of the trial (2012-13, 2013-14, and 2014-15), as well as the 5-year cumulative yield, were not statistically significant $(P<0.15)$.

Juice quality. The legal maturity factors of juice quality include juice percentage, TA, TSS as Brix, and TSS/TA ratio (Wardowski et al., 1995). These parameters were measured after the second, third, and fourth year of the trial. There was no significant statistical interaction between the pruning and nutritional treatments in terms of juice quality measures.

Juice orange growers in Florida are paid on the basis of total soluble solids (TSS), measured as kilogram solids per $(40.8 \mathrm{~kg})$ box. For the 2011-12 and the 2012-13 seasons, fruit from pruned trees averaged significantly higher TSS than nonpruned trees (Table 5). By the fourth year of the trial (2013-14), there were no statistically significant differences among the juice quality parameters between pruned and nonpruned trees. The nutritional treatments did not produce any statistically significant differences among any of the juice quality measures.

Economic evaluation. The total cost of pruning was estimated to be $\$ 1381$ per hectare (Table 6). More than $70 \%$ of these costs were attributable to yield loss in the first year after the pruning. The additional 101 boxes/ha from nonpruned trees in 2010-11 (Table 4) were valued at $\$ 9.71 /$ box (Table 7) as the average on-tree value of 'Valencia' oranges in 2010-11. The remaining costs of pruning $(\$ 400 / \mathrm{ha})$ covered the 
hedging and topping equipment needed to make the actual tree cuts and for front-end loaders and mowers to clear away the resulting debris.

Material costs of the foliar nutritional treatments are shown in Table 8. All plots, including the control, received $2015 \mathrm{~kg} / \mathrm{ha} /$ year of a calcium nitrate dry fertilizer mix plus a micronutrient package. The annual cost of the control foliar spray was $\$ 99 /$ ha, which included \$12.66/ha in materials and \$86.45/ ha for application. Material costs for the Fortress treatments were $\$ 378$ and $\$ 408$ per ha depending on whether $\mathrm{KNO}_{3}$ or urea, respectively, was used. Material cost for the Boyd treatment was higher still at more than $\$ 1021 /$ ha. The Boyd treatment applied considerably more micro- and macronutrients compared with the Fortress treatments (Table 2). The Boyd and Fortress enhanced nutritional treatments required four separate applications that added another $\$ 346 /$ ha of cost.

Table 7. Season average on-tree prices for 'Valencia' oranges during 2010-14 season.

\begin{tabular}{lc}
\hline Season & $\begin{array}{c}\text { On-tree price } \\
(\$ / 40.8 \mathrm{~kg} \text { box })\end{array}$ \\
\hline $2010-11^{\mathrm{z}}$ & $\$ 9.71$ \\
$2011-12^{\mathrm{z}}$ & $\$ 10.99$ \\
$2012-13^{\mathrm{z}}$ & $\$ 8.62$ \\
$2013-14^{\mathrm{y}}$ & $\$ 10.90$ \\
$2014-15^{\mathrm{y}}$ & $\$ 10.61$ \\
Average $(2010-15)$ & $\$ 10.17$ \\
\hline
\end{tabular}

zhttp://www.nass.usda.gov/Statistics_by_State/ Florida/Publications/Citrus/fcs/2013-14/fcs1314. pdf.

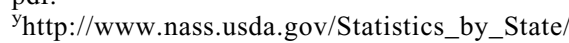
Florida/Publications/Citrus/cspre/cit91715.pdf. Preliminary summary statistics for the 2014-15 season.
All foliar nutritional treatments increased yields in the first and second year of the trial. In 2010-11, the Boyd treatment increased yield above the control by 22.3 boxes/ha, whereas both Fortress treatments increased yield by 33.6 boxes/ha (Table 4 ). In 2011-12, only the Boyd treatment significantly increased yield above the control, and that gain was measured as 123.5 boxes/ ha. In the last 3 years of the trial, none of the foliar nutritional treatments produced a fruit yield significantly greater than the control treatment.

Table 9 summarizes the changes in production, revenue, cost, and net returns compared with the control foliar nutritional treatment. The value of production gain in the first 2 years of the trial was not sufficient to offset the added cost due to any of the enhanced nutritional treatments. Only in 2011-12 was the production gain from Boyd, coupled with 2011-12 fruit prices, high enough to achieve a positive net return. Across the 5-year trial period, the Boyd treatment was estimated to lower grower net income by $\$ 4767 /$ ha compared with the control foliar treatment. Because the Fortress nutritional treatments were less costly, the 5-year cumulative losses in the net income were less than those of the Boyd treatment.

\section{Discussion}

Results from this experiment demonstrated that HLB-affected citrus trees can be revitalized with severe pruning, also known as "buckhorning" and sprayed with a foliar applied nutritional treatment. On pruned trees, individual shoot length was greater than nonpruned trees. In years two and three, the shoot growth on pruned trees remained significantly greater than nonpruned trees. Trees that had previously shown branch dieback in the upper canopy were able to reestablish a healthy canopy and set a fruit crop. Juice quality as measured by maturity factors of percentage juice per fruit, acid, degree Brix, Brix/acid ratio, and TSS (kilogram-solids per box) was similar to the quality of juice from trees before HLB infection. Therefore, the juice quality and fruit size were unaffected by HLB when the trees were treated with any of the foliar nutritionals.

The yield loss experienced in the first year after the severe pruning was expected. Trees were pruned in Feb. 2010 just at the time trees were flowering for the next crop. If severe pruning is to be economically feasible, however, yields from pruned trees in subsequent years would have to not only rebound, but exceed yields from nonpruned trees. Between 2010 and 2015, on-tree Valencia fruit prices averaged $\$ 10.17$ per box (Table 6), which implied the cumulative yield gain from pruned trees would have to be at least 136 boxes per hectare $(\$ 1381 /$ ha cost divided by $\$ 10.17 /$ box fruit price). As shown in Table 4, the yields from unpruned trees were at least equal if not greater than the yields from pruned trees. Hence, severe pruning, as used in this trial, was not cost effective for the 5year period of data collection. It is possible that pruning increases the productive longevity of an HLB-affected tree. If true, however, future yield differences would have to be large enough to offset the "time value of money," which acknowledges the economic reality that a $\$ 1$ gain tomorrow (or 5+ years)

Table 8. Material and application costs of foliar nutrient treatment applied to pruned and nonpruned treatments Huanglongbing affected citrus trees at the University of Florida/Southwest Florida Research and Education Center, Immokalee, FL, season 2010-14.

\begin{tabular}{|c|c|c|c|c|c|c|}
\hline Treatment/materials ${ }^{\mathrm{z}}$ & Unit & Rate (units/application) & $\begin{array}{c}\text { Number of } \\
\text { applications (applications/ha) }\end{array}$ & Price (\$/unit) & Costs $(\$ /$ ha $)$ & Total costs $(\$ / \mathrm{ha})$ \\
\hline \multicolumn{7}{|l|}{ Dry ground fertilizer } \\
\hline $9 \mathrm{~N}-0.4 \mathrm{P}-11.6 \mathrm{~K}$ with micros & $\mathrm{kg}$ & 671.6 & 3 & 0.55 & 1,112 & \\
\hline $\begin{array}{l}\text { Dry application } \\
\text { Control }\end{array}$ & ha & 1 & 3 & 24.70 & 74 & 1,186 \\
\hline Material cost & $\mathrm{L}$ & 4.67 & 1 & 2.71 & 13 & \\
\hline Control application & ha & 1 & 1 & 86.45 & 86 & 99 \\
\hline \multicolumn{7}{|l|}{ Boyd } \\
\hline $3 \mathrm{~N}-7.9 \mathrm{P}-16.6 \mathrm{~K}$ w/KPhite & $\mathrm{L}$ & 64.5 & 4 & 3.71 & 948 & \\
\hline $\mathrm{K}$ & $\mathrm{kg}$ & 1.69 & 4 & 1.59 & 28 & \\
\hline $\mathrm{Mg}$ & $\mathrm{kg}$ & 0.61 & 4 & 0.66 & 4 & \\
\hline $\mathrm{Mn}$ & $\mathrm{kg}$ & 0.34 & 4 & 1.66 & 27 & \\
\hline $\mathrm{Zn}$ & $\mathrm{kg}$ & 1.47 & 4 & 1.99 & 9 & \\
\hline Mo & $\mathrm{g}$ & 9.91 & 4 & 0.05 & 5 & \\
\hline Material cost & & & & & 1,021 & \\
\hline Boyd application & ha & 1 & 4 & 86.45 & 346 & 1,367 \\
\hline \multicolumn{7}{|l|}{ Fortress $/ \mathrm{KNO}_{3}$} \\
\hline Fortress pack & $\mathrm{kg}$ & 2.80 & 4 & 27.59 & 309 & \\
\hline $\mathrm{KNO}_{3}$ & $\mathrm{~kg}$ & 11.2 & 4 & 1.55 & 69 & \\
\hline Materials cost & & & & & 378 & \\
\hline $\begin{array}{l}\text { Fortress application } \\
\text { Fortress/urea }\end{array}$ & ha & 1 & 4 & 86.45 & 346 & 724 \\
\hline Fortress pack & $\mathrm{kg}$ & 2.80 & 4 & 27.59 & 309 & \\
\hline Urea & $\mathrm{L}$ & 18.7 & 4 & 1.32 & 99 & \\
\hline Material cost & & & & & 408 & \\
\hline Fortress application & ha & 1 & 4 & 86.45 & 346 & 754 \\
\hline
\end{tabular}

${ }^{\mathrm{z}} \mathrm{N}=$ nitrogen; $\mathrm{P}=$ phosphorus; $\mathrm{K}=$ potassium; $\mathrm{Mg}=$ magnesium; $\mathrm{Mn}=$ manganese; $\mathrm{Zn}=$ zinc; $\mathrm{Mo}=$ molybdenum.

${ }^{\mathrm{y}} \mathrm{KNO}_{3}=$ potassium nitrate. 
Table 9. Summary of changes to revenue, cost, and net returns from using enhanced foliar nutritional treatment versus the control foliar treatment over the 5-year trial period at the University of Florida/ Southwest Florida Research and Education Center, Immokalee, FL, season 2010-14.

\begin{tabular}{|c|c|c|c|c|}
\hline Season & Unit & Boyd & Fortress $/ \mathrm{KNO}_{3}{ }^{\mathrm{z}}$ & Fortress/urea \\
\hline \multicolumn{5}{|l|}{$2010-11$} \\
\hline Fruit price ${ }^{y}$ & $\$ 9.71 /$ box & & & \\
\hline Yield increase $\mathrm{x}^{\mathrm{x}}$ & box/ha & 22.2 & 33.6 & 33.6 \\
\hline Revenue $^{\mathrm{w}}$ & $\$ /$ ha & 216 & 326 & 326 \\
\hline $\operatorname{Cost}^{v}$ & $\$ /$ ha & 1,268 & 590 & 570 \\
\hline Net return ${ }^{\mathrm{u}}$ & $\$ /$ ha & $(1,052)$ & (264) & $(244)$ \\
\hline \multicolumn{5}{|l|}{ 2011-12 } \\
\hline Fruit price & $\$ 10.99 /$ box & & & \\
\hline Yield & box/ha & 123.5 & 0 & 0 \\
\hline Revenue & $\$ /$ ha & 1,357 & $\$ 0$ & $\$ 0$ \\
\hline Cost & $\$ /$ ha & 1,268 & 590 & 570 \\
\hline Net return & $\$ /$ ha & 89 & $(590)$ & $(570)$ \\
\hline \multicolumn{5}{|l|}{$2012-13$} \\
\hline Fruit price & $\$ 8.62 /$ box & & & \\
\hline Yield & box/ha & 0 & 0 & 0 \\
\hline Revenue & $\$ /$ ha & 0 & $\$ 0$ & $\$ 0$ \\
\hline Cost & $\$ /$ ha & 1,268 & 590 & 570 \\
\hline Net return & $\$ /$ ha & $(1,268)$ & (590) & $(570)$ \\
\hline \multicolumn{5}{|l|}{ 2013-14 } \\
\hline Fruit price & $\$ 10.90 /$ box & & & \\
\hline Yield & box/ha & 0 & 0 & 0 \\
\hline Revenue & $\$ /$ ha & $\$ 0$ & $\$ 0$ & $\$ 0$ \\
\hline Cost & $\$ /$ ha & 1,268 & $\$ 590$ & $\$ 570$ \\
\hline Net return & $\$ /$ ha & $(1,268)$ & $(\$ 590)$ & $(\$ 570)$ \\
\hline \multicolumn{5}{|l|}{$2014-15$} \\
\hline Fruit price & $\$ 10.61 /$ box & & & \\
\hline Yield & box/ha & 0 & 0 & 0 \\
\hline Revenue & $\$ /$ ha & 0 & 0 & $\$ 0$ \\
\hline Cost & $\$ /$ ha & 1,268 & 590 & 570 \\
\hline Net return & $\$ /$ ha & $(1,268)$ & $(590)$ & $(570)$ \\
\hline Cumulative change in net income, 2011-15 & $\$ /$ ha & $(4,767)$ & $(2,624)$ & $(2,524)$ \\
\hline
\end{tabular}

${ }^{\mathrm{z}} \mathrm{KNO}_{3}=$ potassium nitrate.

${ }^{\mathrm{y}}$ From Table 7.

${ }^{\mathrm{x}}$ Yield, change in yield from control foliar treatment. See Table 4.

${ }^{\mathrm{w}}$ Revenue, change in revenue/ha; fruit price multiplied by yield change.

${ }^{\mathrm{v}}$ Cost, change in cost from control foliar treatment. See Table 7.

${ }^{\mathrm{u}}$ Net return, change in net returns; revenue minus cost changes.

is worth less than $\$ 1$ (or $\$ 1381 / \mathrm{ha}$ ) spent today.

Although "buckhorning" may not be cost effective, several growers and several citrus care service companies are experimenting with varying degrees of "lighter" pruning (personal communication, Bob Ford, Lake Placid Citrus Grove Care Company, Lake Placid, FL). Growers are pruning off the upper portions of tree canopies that have been severely impacted by HLB while maintaining the lower portion of the tree to produce a crop and a cash flow in the years after the pruning. This imaginative and less destructive pruning practice adopted by growers avoids the costs of tree removal and purchase of new trees, replanting, several years of care costs to bring new trees into production, and maintenance of the trees until they are economically productive. Additional experiments are needed to determine the economic gains of this grower-adapted management practice to rehabilitate declining HLB-affected citrus trees.

The enhanced foliar nutritional treatment increased yields in the first two years compared with standard micronutrient application. However, the enhanced foliar nutritional treatments did not prove to be cost effective.

\section{Literature Cited}

Albrecht, U., G. McCollum, and K.D. Bowman. 2012. Influence of rootstock variety on Huanglongbing disease development in field-grown sweet orange (Citrus sinensis L. Osbeck) trees. Sci. Hort. 138:210-220.

Bové, J.M. 2006. Huanglongbing: A destructive, newly-emerging century-old disease of citrus. J. Plant Pathol. 88:7-37.

Davies, F.S. and L.K. Jackson. 2009. Citrus growing in Florida. 5th ed. Univ. Florida Press, Gainesville, FL.

Fake, C. 2012. Pruning citrus. Univ. Calif. Ext. 4 Feb. 2016. <http://ucanr.edu/sites/ placernevadasmallfarms/files/134946.pdf>.

Florida Agricultural Statistics Service. 2014. Florida citrus statistics 2013-2014. 4 Feb. 2016. $<\mathrm{http} / / /$ www.nass.usda.gov/Statistics_by State/Florida/Publications/Citrus/fcs/2013-14/ fcs1314.pdf>.

Gottwald, T.R., J.H. Graham, M.S. Irey, T.G. McCollum, and B.W. Wood. 2012. Inconsequential effect of nutritional treatments on huanglongbing control, fruit quality, bacterial titer, and disease progress. Crop Prot. 36:7382.

Li, W., J.S. Hartung, and L. Levy. 2006. Quantitative real-time PCR for detection and identification of Candidatus Liberibacter species associated with citrus huanglongbing. J. Microbiol. Methods 66:104-115.

Minolta. 1989. SPAD-502 owner's manual. Industrial Meter Div. Minolta Corp., Ramsey, NJ.

Nesbitt, M.L. 2010. Citrus freeze injury and care. Texas Agrilife Ext. Serv., Texas A\&M Univ. 4 Feb. 2016. <http://aggiehorticulture.tamu.edu/ newsletter/hortupdate/2010/jan_feb/citrusfreeze.html>.

Obreza, T.A. and M.E. Collins. 2008. Common soils used for citrus production in Florida. SL 193. Florida Coop. Ext. Serv., Gainesville, FL.

Obreza, T.A. and K. Morgan. 2008. Nutrition of Florida citrus trees. 2nd ed. SL253. Soil and Water Science Dept., Florida Coop. Ext. Serv., Inst. of Food and Agr. Sci., Univ. Florida, Gainesville, FL.

Roka, F.M., A. Singerman, and R.P. Muraro. 2015. Summary of 2013-2014 production costs for Indian River fresh market grapefruit and Southwest Florida juice oranges. Univ. Florida, Inst. Food Agr. Sci., Electronic Data Info. Source, EDIS FE968. 4 Feb. 2016. <https://edis.ifas.ufl. edu/pdffiles/FE/FE96800.pdf>.

Rouse, R., P. Roberts, M. Irey, M. Boyd, and T. Willis. 2010. Monitoring trees infected with Huanglongbing in a commercial grove receiving nutritional/SAR foliar sprays in southwest Florida. Proc. Annu. Mtg. Fla. State Hort. Soc. 123:118-120.

Rouse, R., P. Roberts, M. Irey, M. Boyd, and T. Willis. 2012. Fruit production in a southwest Florida citrus grove using the Boyd nutrient/ SAR foliar spray. Proc. Annu. Meet. Fla. State Hort. Soc. 125:61-64.

Rouse, R. and M. Zekri. 2012. Citrus culture in the home landscape. Univ. Florida, Inst. Food Agr. Sci., Electronic Data Info. Source, HS-867/ HS132. 4 Feb. 2016. <http://edis.ifas.ufl.edu/ pdffiles/HS/HS13200.pdfs.

Rouse, R. and H. Wutscher. 1985. Heavy soil and bud union crease with some grapefruit clones limit use of Swingle citrumelo rootstock. HortScience 20:259-261.

Spann, T.M. and R.J. Heerema. 2010. A simple method for non-destructive estimates of total shoot leaf area in tree fruit crops. Sci. Hort. 125 (3):528-533.

Wardowski, W., J. Whigham, W. Grierson, and J. Soule. 1995. Quality tests for Florida citrus. Univ. of Florida., IFAS, Coop. Ext. Serv., SP 99. 4 Feb. 2016. <http://irrec.ifas.ufl.edu/postharvest/pdfs/Quality_Tests_for_FL_CitrusSP_99.pdf>.

Wright, G.C. and J. Kelly. 2008. Pruning citrus. Univ. Arizona. Coop. Ext. Serv., AZ 1455. 4 Feb. 2016. <http://extension.arizona.edu/sites/ extension.arizona.edu/files/pubs/az1455.pdf>.

Yadava, U.L. 1985. A rapid and nondestructive method to determine chlorophyll in intact leaves. HortScience 21:1449-1450.

Zekri, M. and R. Rouse. 2013. Citrus problems in the home landscape. Univ. Florida, Inst. Food Agr. Sci., Electronic Data Info. Source, HS876/HS132. 4 Feb. 2016. <https://edis.ifas.ufl. edu/pdffiles/HS/HS14100.pdf>. 